\title{
Co-Relationship between California Bearing Ratio and Index Properties of Jamshoro Soil
}

\author{
FAISAL IQBAL*, ANEEL KUMAR*, AND ALI MURTAZA* \\ RECEIVED ON 28.12.2016 ACCEPTED ON 29.05.2017
}

\begin{abstract}
Subgrade is a most important part of a pavement structure, which should have a reasonable stiffness modulus and shear strength. CBR (California Bearing Ratio) test is performed to evaluate stiffness modulus and shear strength of subgrade soils. However, CBR test is laborious and time consuming, particularly when soil is highly plastic like Jamshoro soil. In order to overcome this limitation, it may be appropriate to correlate CBR value of soil with its index properties like grain size analysis, Atterberg limits, and compaction characteristics such as MDD (Maximum Dry Density) and OMC (Optimum Moisture Content). This paper expresses the correlations between CBR value of Jamshoro soil and its index properties. SLRA(Single Linear Regression Analysis) and MLRA(Multiple Linear Regression) based Models were utilized. It is seen that MLRA gave better correlations up to $\mathrm{R}^{2}$ of about 0.984 . It is observed that the Soaked CBR value can be predicted with confidence from LL (Liquid Limit), PI (Plasticity Index) and percent finer while the un-soaked CBR value can be obtained from LL, plasticity index and MDD.
\end{abstract}

Key Words: Jamshoro Soil, Index Properties, Single Linear Regression Analysis, Multiple Linear Regression Analysis, Predicted California Bearing Ratio, Coefficient of Determination.

\section{INTRODUCTION}

$\mathrm{P}$ avement design is considered to be the most important parameter in the construction of a road network. Generally, pavement, a relatively stable crust, is constructed over the natural soil in order to support the wheel and traffic loads as well as to provide a hard, durable and abrasion resistant surface [1]. A flexible pavement consist of a number of layers including sub-base, base course, surfacing etc. which ultimately lies on subgrade. Basically, subgrade is not the physical part of the pavement but it is considered as the functional part of the pavement. It is necessary that the subgrade soil should be properly compacted to fully utilize its strength while carrying the loads of the above layers of pavements as well as the moving loads of traffic [2]. For this purpose, it is necessary to evaluate the strength of subgrade soil on which the whole structure of the pavement rests and for this, CBR is one of the most widely used methods. This method is mainly used to determine the stiffness modulus and shear strength of the subgrade soil and helps in designing the thickness of each layer of

Corresponding Author (E-Mail: aneel.kumar@faculty.muet.edu.pk)

* Department of Civil Engineering, Mehran University of Engineering \& Technology, Jamshoro.

Mehran University Research Journal of Engineering \& Technology, Volume 37, No. 1, January, 2018 [p-ISSN: 0254-7821, e-ISSN: 2413-7219] 
pavement [3-4]. If the subgrade has higher CBR value, this means that it has more strength and will be able to bear more traffic load coming over it and ultimately the thickness of pavement layers will be small and vice versa [5]. The soaked CBR value of the subgrade soil is of great importance, which is required to be determined as it helps in assessing the swelling potential and almost the actual strength of subgrade soil over the entire road length.

Though this conventional method helps in evaluating the strength of the subgrade soil by obtaining its soaked CBR value, but it is quite time consuming and laborious method and also its reproducibility is low [1]. Moreover, this test is costly as it involves a high level technical supervision and quality control assessment. Therefore, more samples are required to be tested in order to achieve better accuracy and to obtain proper idea about the soaked CBR value of subgrade materials over the entire length of the road which is quite difficult because it is difficult to take large number of samples. This would result in serious delay in the progress of the project, since in most situations the materials for earthwork construction come from highly variable sources. Any delay in construction inevitably leads to rise of project cost [1,4-6].

In Pakistan, most of the roads are designed as flexible pavements. Nowadays, infrastructure development in the country, particularly in Sindh province is quite fast. Development of road networks, particularly the highway is at its peak in order to connect the rural and urban areas, production and market places, and other basic infrastructures like hospitals, public buildings, public health and sanitation sector which includes proper water supply and sewage treatment systems, irrigation sector [4] etc. Due to the increasing development of road networks, it has become quite imperative to speed up the construction works and this CBR test may cause delay in the progress of the project.
This research paper is written on Jamshoro Soil. Jamshoro is the capital of Jamshorodistrict, which includes the cities namely Kotri, Nooriabad, ThanoBula Khan and Jamshoro itself. It is located on the right bank of Indus River, approximately $18 \mathrm{~km}$ Northwest of Hyderabad and $150 \mathrm{~km}$ Northeast from Karachi, the Capital of Sindh Province. The soil is dark yellow brown in color and mostly contains clay, silt and shale particles along with limestone mixed in it. Out of these, the major soil element encountered in this Jamshoro soil is shale. Shale is a fine-grained sedimentary rock that forms from the compaction of silt and clay-size mineral particles. This type of rock is very much fissile and laminated [7-9].

The Jamshoro soil has been observed to create many problems in highway works such as rutting due to the shale content in it. It is also found that this soil is very much problematic in the construction of roads and buildings because of its low bearing capacity as well as large changes in the volume due to its expansive nature. The swelling potential of this soil is very much high and variable. The soil becomes stiff with an irregular increase in its plasticity and sticks to the rammer with the increase in moisture content due to which it is quite difficult to transfer the proctor compaction energy to the samples [7-9]. Similar problems are observed during the CBR testing of this soil. While determining the soaked CBR value, this soil shows varying swelling potential when placed in the soaking tub under water. Most of the soils show high swelling potential while some of them show low potential, whicharises the need of repeating the test to clear the doubts, thus ultimately leading to increased construction cost.

By keeping in view the above problems of Jamshoro soil and the above mentioned factors as well as the present condition of infrastructure development in the province, there arises a need to develop suitable correlations between CBR value and the index properties of Jamshoro

Mehran University Research Journal of Engineering \& Technology, Volume 37, No. 1, January, 2018 [p-ISSN: 0254-7821, e-ISSN: 2413-7219] 
soil which includes LL, PL (Plastic Limit), PI (Plasticity Index), OMC, MDD, percentage passing of soil fines $(\% \mathrm{~F})$ by the help of SLRA and MLRA which is the main theme of this research work.

This paper mentions important correlations which have been developed through SLRA and MLRA on CBR and index properties of various soil samples in Jamshoro. Index properties and CBR values of these samples have been determined through laboratory testing according to AASHTO and ASTM procedures. Though less number of samples have been analyzed but this paper provides a way of developing relationship between the properties. The major benefit from this research outcome is that the developed correlations will be utilized for directly obtaining strength of Jamshoro soil instead of performing tests on this highly plastic soil, thus avoiding unnecessary consumption of time and delay in project construction. Moreover, this will provide an advantage to the designers and constructors as they will be knowing already that which important properties are required to be determined for knowing the accurate strength of soil and thus, they will only perform those tests which will determine those important properties instead of performing all tests.

\section{METHODOLOGY}

\subsection{Single Linear Regression Analysis}

A SLRA provides an attempt to develop a correlation between two variables only in which one is the response (dependent) variable and other is the explanatory (independent) variable. In this research work, CBR is the dependent variable and each individual IP of soil is independent variable. Graph is plotted between CBR and IP and a suitable trend line is drawn through the plotted points for obtaining the value of coefficient of determination $\left(R^{2}\right)$. The value of $R^{2}$ provides a measure of how well the future outcomes are likely to be predicted by the model [10]. Generally speaking, any correlation greater than 0.88 is usually considered as a best fit.

\subsection{Multiple Linear Regression Analysis}

A MLRA provides an attempt to develop a correlation between more than two variables. One is the response (dependent variable) and others are explanatory (independent) variables. In this research work, CBR is the dependent variable and all other IP are independent variables. In the equation, CBR value is the function of all other index properties. Mathematically:

$\mathrm{CBR}=\mathrm{f}(\% \mathrm{~F}, \mathrm{LL}, \mathrm{PI}, \mathrm{OMC}, \mathrm{MDD})$

The equation will be created as follows:

$\mathrm{Y}=\mathrm{b}_{\mathrm{o}}+\mathrm{b}_{1} \mathrm{x}_{1}+\mathrm{b}_{2} \mathrm{x}_{2}+\mathrm{b}_{3} \mathrm{x}_{3}+\mathrm{b}_{4} \mathrm{x}_{4}+\ldots \ldots \mathrm{b}_{\mathrm{n}} \mathrm{x}_{\mathrm{n}}$

Whereb $\mathrm{b}_{\mathrm{o}}, \mathrm{b}_{1}, \mathrm{~b}_{2}, \mathrm{~b}_{3}, \mathrm{~b}_{4}, \mathrm{~b}_{\mathrm{n}}$ are constants, $\mathrm{Y}$ is CBR and, $\mathrm{x}_{1}$, $\mathrm{x}_{2}, \mathrm{x}_{3}, \mathrm{x}_{4}, \mathrm{x}_{\mathrm{n}}$ are soil properties considered for analysis.

The values of these constants can be obtained by using Data Analysis Tool bar of Microsoft Excel and then putting these values with their corresponding soil properties in order to obtain a suitable equation [10].

\section{EXPERIMENTAL PROGRAM}

The samples for this research work have been collected from various places within the closed proximity of MUET (Mehran University of Engineering \& Technology), Jamshoro, Pakistan. Seven (7) samples have been collected from depths of about 2-3 feet and laboratory tests for LL, PL, PI, particle size distribution, OMC, MDD and CBR values (both soaked and unsoaked) have been performed on these samples at Geotechnical Laboratory, Department of Civil Engineering, MUET, Jamshoro according to AASHTO and ASTM specifications [11-14]. The soil classifications of these samples have been done according to AASHTO method. The results are given in Table 1 along with \% finer passing from \#200 sieve (\%F) for each sample.

Mehran University Research Journal of Engineering \& Technology, Volume 37, No. 1, January, 2018 [p-ISSN: 0254-7821, e-ISSN: 2413-7219] 


\section{RESULTS AND DISCUSSION}

Table 1 summarizes the results of different soil properties from the experiments conducted in the laboratory for seven samples collected from different locations. Sample Nos. 3 and 4 were classified as A- 4 soils and such soils have very less presence in Jamshoro. Therefore, these samples are not considered for developing correlations. The range of other soil properties studied in this research work are: $\mathrm{PL}=16.49-29.14 \%, \mathrm{PI}=20.31-29.26 \%$ [5]. The graphs representing laboratory test results for above samples are presented below.

Fig. 1 presents the PSD of the soil samples tested. It is observed that the range of \% finer considered for developing correlations by neglecting curves of sample 3 and 4 because of their irregular behavior comes out to be $58.709-84.794 \%$. Further, the diameters of particles corresponding to $10 \%$ (D10), 30\% (D30) and 60\% (D60) passing are plotted for all samples through which $\mathrm{Cu}$ (Coefficient of Uniformity) and Cc (Coefficient of Curvature) is determined which helps in determining whether the soil is well graded or poorly graded.
Table 2 presents the D10, D30, D60, together with the $\mathrm{Cu}$ and $\mathrm{Cc}$. The $\mathrm{Cu}$ is the ratio of $\mathrm{D} 60$ by $\mathrm{D} 10$ given by Equation (3):

$\mathrm{Cu}=\mathrm{D} 60 / \mathrm{D} 10$

Whereas, the $\mathrm{Cu}$ is the ratio of square of $\mathrm{D} 30$ by product of D60 and D10 and is given by Equation (4):

$\mathrm{Cc}=(\mathrm{D} 30)^{2} /(\mathrm{D} 60 * \mathrm{D} 10)$

If $\mathrm{Cu}$ is greater than 4-6 and $\mathrm{Cc}$ lies between 1 and 3, the soil is well graded otherwise it is poorly graded.

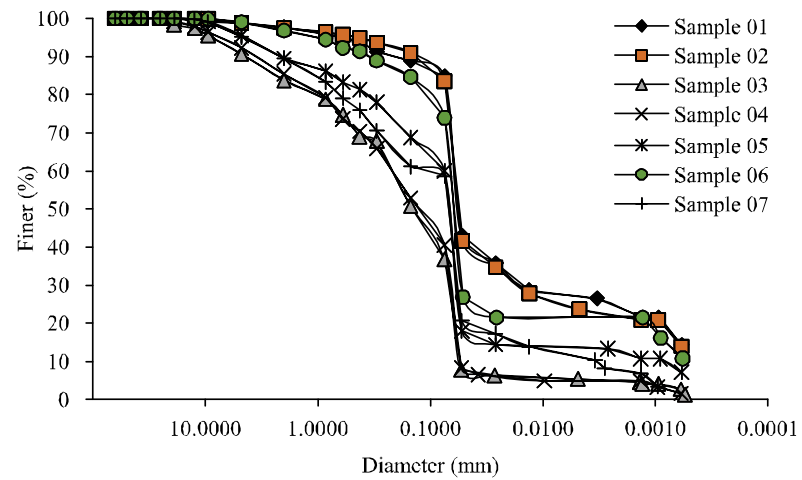

FIG. 1. PARTICLE SIZE DISTRIBUTION CURVES FOR ALL SOIL SAMPLES

TABLE 1. LABORATORY TEST RESULTS FOR SOIL SAMPLES

\begin{tabular}{|c|c|c|c|c|c|c|c|c|c|c|c|}
\hline \multirow{2}{*}{$\begin{array}{l}\text { Sample } \\
\text { No. }\end{array}$} & \multirow{2}{*}{$\% \mathrm{~F}$} & \multirow{2}{*}{$\mathrm{Cu}$} & \multirow{2}{*}{ Cc } & \multirow{2}{*}{$\begin{array}{l}\text { LL } \\
(\%)\end{array}$} & \multirow{2}{*}{$\begin{array}{l}\text { PL } \\
\text { (\%) }\end{array}$} & \multirow{2}{*}{$\begin{array}{l}\text { PI } \\
(\%)\end{array}$} & \multicolumn{2}{|c|}{$\begin{array}{c}\text { Compaction } \\
\text { Characteristics }\end{array}$} & \multicolumn{2}{|c|}{ CBR Values } & \multirow{2}{*}{$\begin{array}{l}\text { Soil } \\
\text { Type }\end{array}$} \\
\hline & & & & & & & $\begin{array}{l}\mathrm{OMC} \\
(\%)\end{array}$ & $\begin{array}{c}\mathrm{MDD} \\
\left(\mathrm{gm} / \mathrm{cm}^{3}\right)\end{array}$ & $\begin{array}{c}\text { Unsoaked } \\
\text { (\%) }\end{array}$ & $\begin{array}{l}\text { Soaked } \\
(\%)\end{array}$ & \\
\hline 1 & 84.794 & 133.33 & 9.48 & 47.00 & 22.48 & 24.52 & 14.58 & 1.844 & 33.465 & 8.418 & \multirow{2}{*}{$\begin{array}{c}\text { A-7-6 } \\
\text { (Poorly } \\
\text { Graded) }\end{array}$} \\
\hline 2 & 83.421 & 125.00 & 11.25 & 46.70 & 22.60 & 24.10 & 12.71 & 1.915 & 41.310 & 17.892 & \\
\hline 3 & 36.757 & 3.793 & 0.384 & 21.70 & 13.20 & 8.50 & 8.14 & 2.114 & 64.171 & 33.742 & \multirow{2}{*}{$\begin{array}{c}\text { A-4 } \\
\text { (Poorly } \\
\text { Graded) }\end{array}$} \\
\hline 4 & 40.594 & 4.000 & 0.349 & 23.80 & 14.84 & 8.96 & 9.03 & 2.125 & 11.952 & 4.558 & \\
\hline 5 & 60.092 & 88.889 & 50.000 & 36.80 & 16.49 & 20.31 & 10.50 & 2.025 & 22.059 & 13.302 & $\begin{array}{c}\text { A-6 } \\
\text { (Poorly } \\
\text { Graded) }\end{array}$ \\
\hline 6 & 73.977 & 108.333 & 77.564 & 57.00 & 28.10 & 28.90 & 12.90 & 1.910 & 15.571 & 10.002 & \multirow{2}{*}{$\begin{array}{c}\text { A-7-6 } \\
\text { (Poorly } \\
\text { Graded) }\end{array}$} \\
\hline 7 & 58.709 & 22.857 & 12.857 & 58.40 & 29.14 & 29.26 & 15.50 & 1.740 & 45.185 & 19.805 & \\
\hline
\end{tabular}

Mehran University Research Journal of Engineering \& Technology, Volume 37, No. 1, January, 2018 [p-ISSN: 0254-7821, e-ISSN: 2413-7219] 
Fig. 2 shows LL curves showing LL corresponding to 20 mm penetration for all the soil samples tested in the laboratory. Curve of Sample-7 gives the highest liquid limit of about $58.40 \%$ and curve of Sample-3 gives the least liquid limit value of $21.70 \%$. As Samples 3 and 4 were neglected in developing correlations, the least LL is considered to be $36.80 \%$ corresponding to Sample-5. Thus, the range of LL considered for developing correlations is $36.80-58.40 \%$.

Fig. 3 shows compaction curves with their peak points representing OMC and MDD of all the soil samples. Neglecting the results of Samples 3 and 4, the lowest MDD comes out to be $1.740 \mathrm{gm} / \mathrm{cm}^{3}$ for Sample-7 and highest MDD is $2.025 \mathrm{gm} / \mathrm{cm}^{3}$ for Sample-5. Thus, the range considered is $1.740-2.025 \mathrm{gm} / \mathrm{cm}^{3}$. Similarly, the lowest OMC observed from the graph is $10.50 \%$ for Sample5 and the highest is $15.50 \%$ for Sample-7. Thus, the range of OMC considered is $10.50-15.50 \%$.

Fig. 4 shows load penetration curves, which help in determining the Unsoaked CBR values at 2.5and 5mm penetration respectively for all soil samples. The highest of both penetrations is considered as the CBR value of that particular sample. From Fig. 4, it has been observed that the range of Unsoaked CBR value considered for developing correlations is 15.571-45.185\%.
Fig. 5 shows load penetration curves, which help in determining the Soaked CBR values at 2.5 and $5 \mathrm{~mm}$ penetration respectively for all soil samples. From the graph, it has been observed that the range of Soaked CBR value considered for developing correlations is 8.418$19.805 \%$.

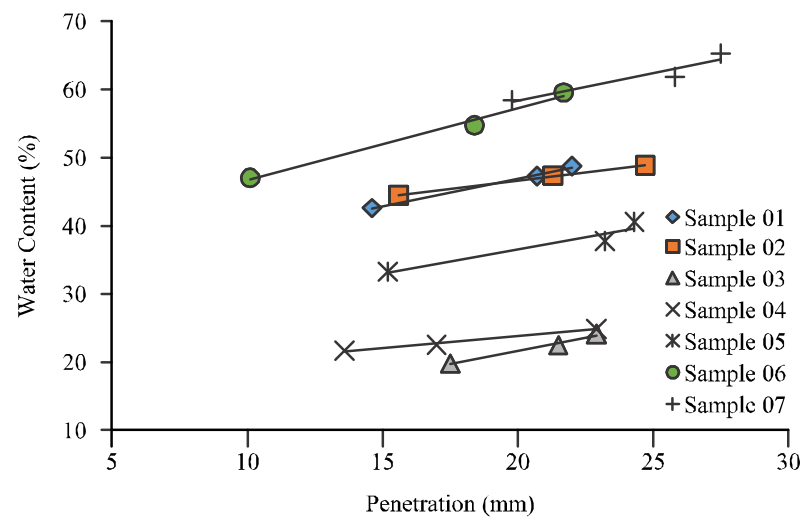

FIG. 2. LIQUID LIMIT CURVES FOR ALL SOIL SAMPLES

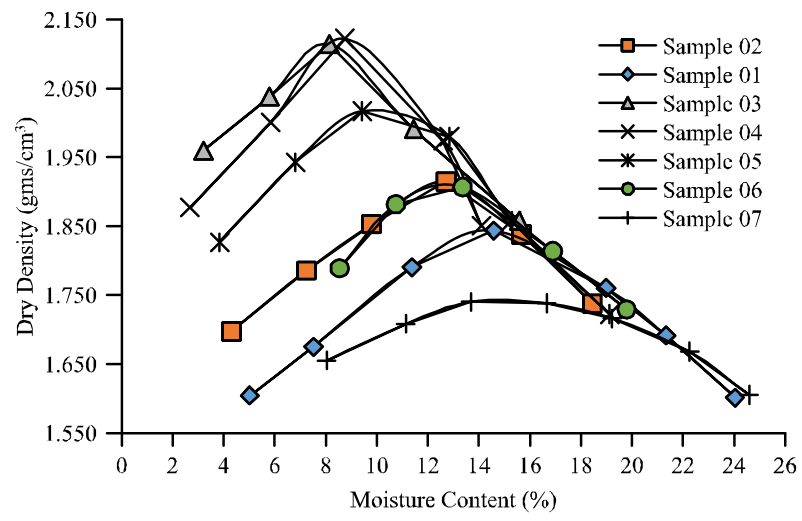

FIG. 3. COMPACTION CURVES FOR ALL SOIL SAMPLES

TABLE 2. SUMMARY OF D10, D30, D60, CU, CC AND SOIL TYPE FOR ALL SOIL SAMPLES

\begin{tabular}{|c|c|c|c|c|c|c|}
\hline Sample No. & D10 & D30 & D60 & Cu & Cc & Soil Type \\
\hline 1 & 0.00045 & 0.016 & 0.06 & 133.333 & 9.481 \\
\hline 2 & 0.00048 & 0.018 & 0.06 & 125.000 & 11.250 \\
\hline 3 & 0.058 & 0.07 & 0.22 & 3.793 & 0.384 \\
\hline 4 & 0.055 & 0.065 & 0.22 & 4.000 & 0.349 \\
\hline 5 & 0.0008 & 0.06 & 0.074 & 92.500 & 60.811 \\
\hline 6 & 0.0006 & 0.055 & 0.065 & 108.333 & 77.564 \\
\hline 7 & 0.0035 & 0.06 & 0.08 & 22.857 & 12.857 \\
\hline
\end{tabular}

Mehran University Research Journal of Engineering \& Technology, Volume 37, No. 1, January, 2018 [p-ISSN: 0254-7821, e-ISSN: 2413-7219] 


\section{CORRELATIONS/MODELS}

The table of laboratory test results along with the graphs is presented in section 3. Now, correlations/models are developed in the form of linear equations between CBR values and various index properties first by SLRA and then collectively by MLRA.

\subsection{Correlations By Single Linear Regression Analysis}

The correlations by SLRA were developed and are described in Model 1- 11 (Fig. 6-16) indicating linear relationship between the variables. Some models gave very low values of reliability $\mathrm{R}^{2}$. However, in this paper, all models are shown:

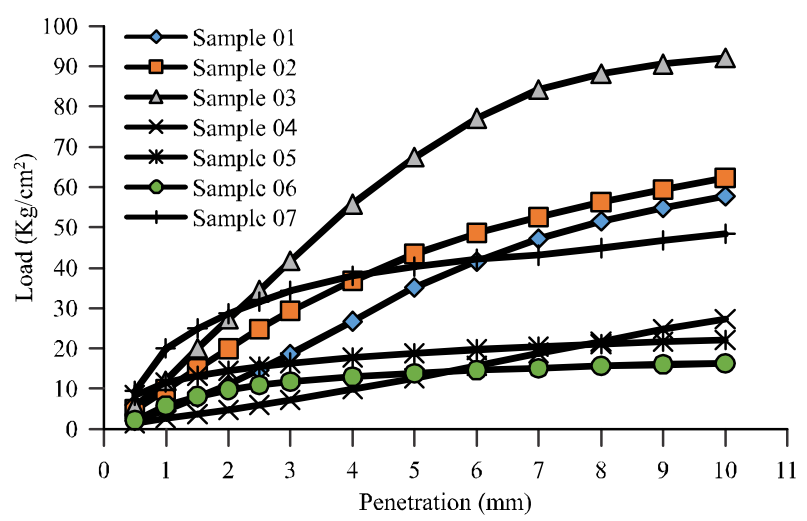

FIG. 4. LOAD-PENETRATION CURVES FOR DETERMINING UNSOAKED CBR FOR ALL SAMPLES

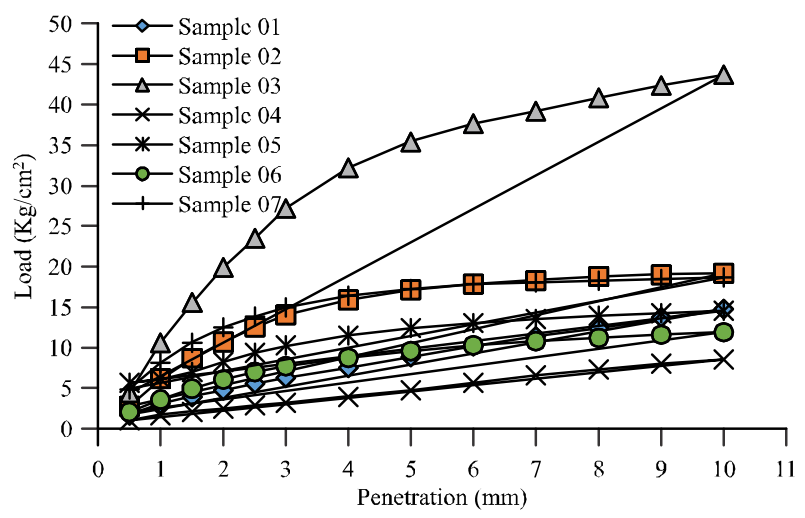

FIG. 5. LOAD-PENETRATION CURVES FOR DETERMINING SOAKED CBR OF ALL SOIL SAMPLES
Model-1: Correlation of Unsoaked California Bearing Ratio $\left(\mathrm{CBR}_{\mathrm{U}}\right)$ With Liquid Limit: Fig. 6 represents a graph, which shows a correlation between unsoaked CBR and LL for all soil samples. The mathematical relation between the two parameters is shown in Equation (5). It can be seen that the reliability factor $\mathrm{R}^{2}$ obtained from this equation is only 0.0413 .

$\mathrm{CBR}_{\mathrm{U}}=0.2896(\mathrm{LL})+17.274 \mathrm{R}^{2}=0.0413$

Model-2: Correlation of Unsoaked California Bearing Ratio with Plasticity Index: Fig. 7 represents a graph, which shows a correlation between unsoaked CBR and PI for all soil samples. The mathematical relation between the two parameters is shown in Equation (6). It can be seen that the reliability factor $\mathrm{R}^{2}$ obtained from this equation is only 0.0268 .

$\mathrm{CBR}_{\mathrm{U}}=0.5519(\mathrm{PI})+17.489 \quad \mathrm{R}^{2}=0.0268$

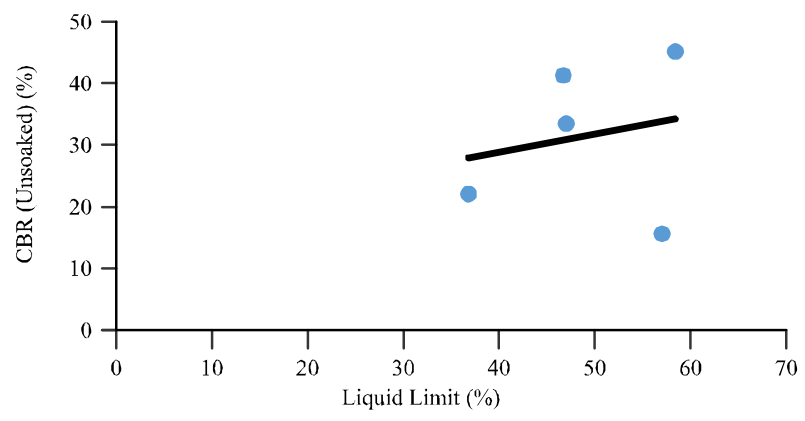

FIG. 6. RELATIONSHIP OF UNSOAKED CBR WITH LIQUID LIMIT

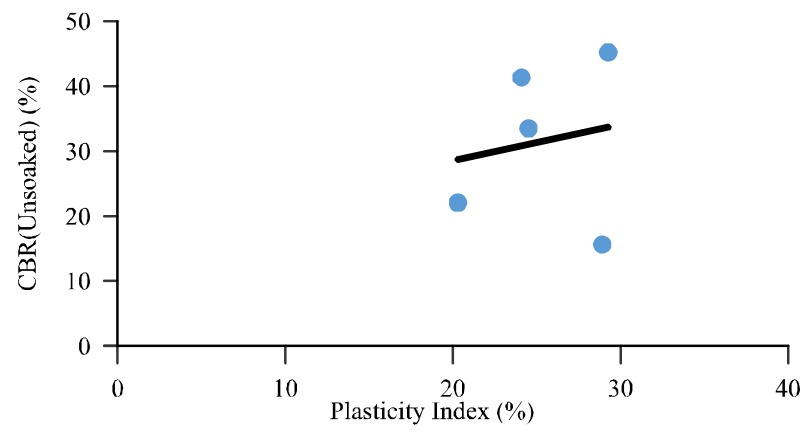

FIG. 7. RELATIONSHIP OF UNSOAKED CBR WITH PLASTICITY INDEX

Mehran University Research Journal of Engineering \& Technology, Volume 37, No. 1, January, 2018 [p-ISSN: 0254-7821, e-ISSN: 2413-7219] 
Model-3: Correlation of Unsoaked California Bearing Ratio with Optimum Moisture Content: Fig. 8 represents a graph, which shows a correlation between unsoaked CBR and OMC for all soil samples. The mathematical relation between the two parameters is shown in Equation (7). It can be seen that the reliability factor $\mathrm{R}^{2}$ obtained from this equation is 0.3812 , which is still not significant.

$\mathrm{CBR}_{\mathrm{U}}=4.0282(\mathrm{OMC})-21.807 \quad \mathrm{R}^{2}=0.3812$

Model-4: Correlation of Unsoaked California Bearing Ratio with Maximum Dry Density: Fig. 9 represents a graph, which shows a correlation between unsoaked CBR and MDD for all soil samples. The mathematical relation between the two parameters is shown in Equation (8). It can be seen that the reliability factor $\mathrm{R}^{2}$ obtained from this equation is 0.4413 , which is still not significant.

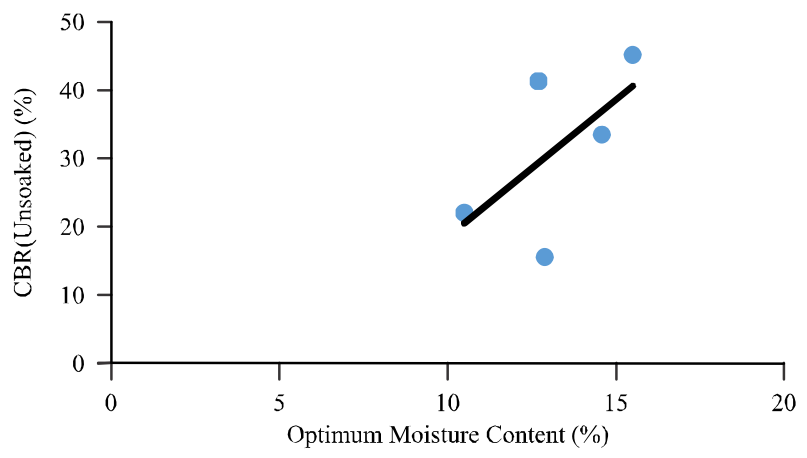

FIG. 8. RELATIONSHIP OF UNSOAKED CBR WITH OPTIMUM MOISTURE CONTENT

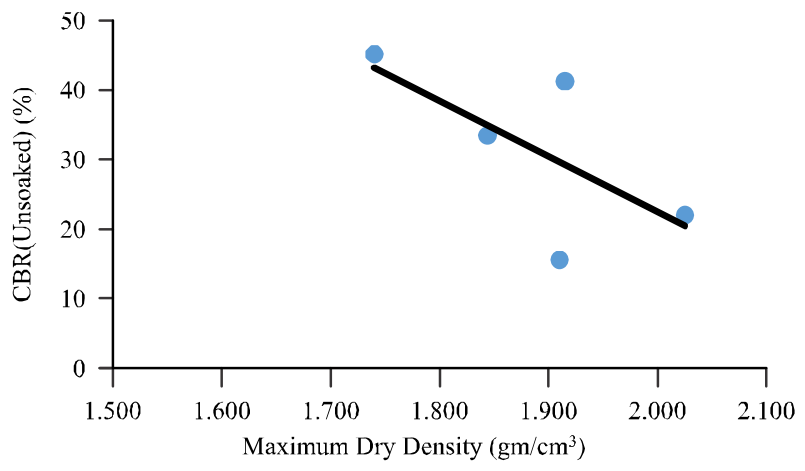

FIG. 9. RELATIONSHIP OF UNSOAKED CBR WITH MAXIMUM DRY DENSITY
$\mathrm{CBR}_{\mathrm{U}}=-79.67(\mathrm{MDD})+181.84 \quad \mathrm{R}^{2}=0.4413$

Model-5: Correlation of Unsoaked California Bearing Ratio with \%Finer Passing From \#200 Sieve (\%F):

Fig. 10 represents a graph which shows a correlation between unsoaked CBR and \% finer passing from \#200 sieve for all soil samples. The mathematical relation between the two parameters is shown in Equation (9). It can be seen that the reliability factor $\mathrm{R}^{2}$ obtained from this equation is only 0.0034 .

$\mathrm{CBR}_{\mathrm{U}}=0.0587(\% \mathrm{~F})+27.276 \quad \mathrm{R}^{2}=0.0034$

Model-6: Correlation of Soaked California Bearing Ratio (CBR $_{\text {S }}$ ) With Liquid Limit: Fig. 11 represents a graph, which shows a correlation between soaked CBR and LL for all soil samples. The mathematical relation between the two parameters is shown in Equation (10). It can be seen that the reliability factor $\mathrm{R}^{2}$ obtained from this equation is only 0.0373 .

$\mathrm{CBR}_{\mathrm{S}}=0.1077(\mathrm{LL})+8.5882 \quad \mathrm{R}^{2}=0.0373$

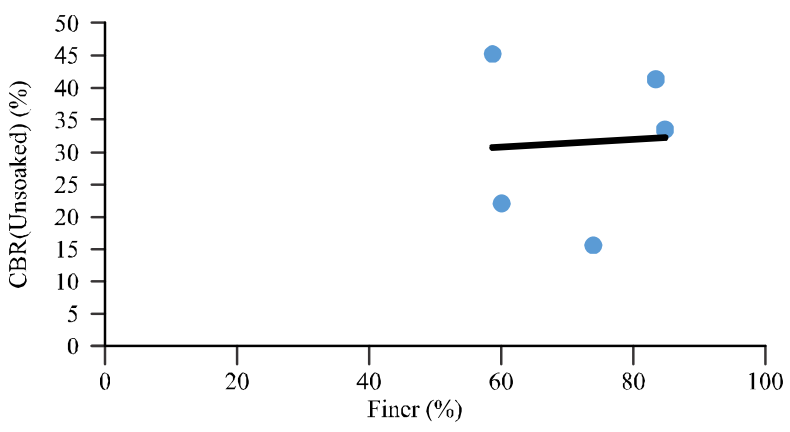

FIG. 10. RELATIONSHIP OF UNSOAKED CBR WITH \% FINER

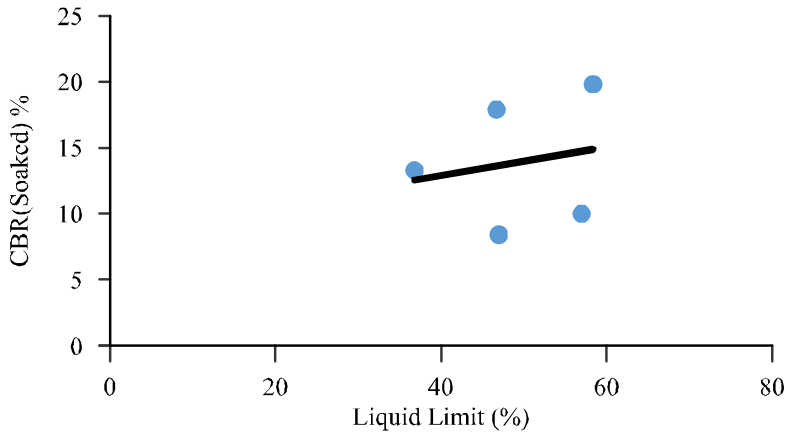

FIG. 11. RELATIONSHIP OF SOAKED CBR WITH LIQUID LIMIT

Mehran University Research Journal of Engineering \& Technology, Volume 37, No. 1, January, 2018 [p-ISSN: 0254-7821, e-ISSN: 2413-7219] 
Model-7: Correlation of Soaked California Bearing Ratio

with Plasticity Index: Fig. 12 represents a graph, which shows a correlation between soaked CBR and PI for all soil samples. The mathematical relation between the two parameters is shown in Equation (11). It can be seen that the reliability factor $\mathrm{R}^{2}$ obtained from this equation is 0.0261 .

$\mathrm{CBR}_{\mathrm{S}}=0.2131(\mathrm{PI})+8.4678 \quad \mathrm{R}^{2}=0.0261$

Model-8: Correlation of Soaked California Bearing Ratio with Optimum Moisture Content: Fig. 13 represents a graph, which shows a correlation between soaked CBR and OMC for all soil samples. The mathematical relation between the two parameters is shown in Equation (12). It can be seen that the reliability factor $\mathrm{R}^{2}$ obtained from this equation is only 0.0328 .

$\mathrm{CBR}_{\mathrm{S}}=0.4624(\mathrm{OMC})+7.7621 \quad \mathrm{R}^{2}=0.0328$

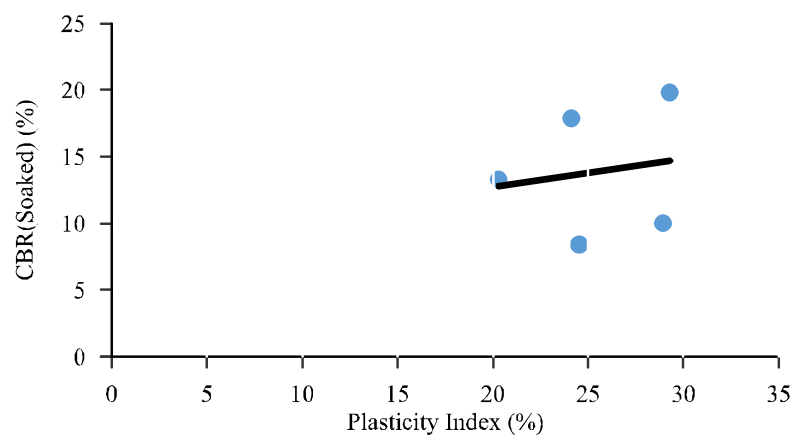

FIG. 12. RELATIONSHIP OF SOAKED CBR WITH PLASTICITY INDEX

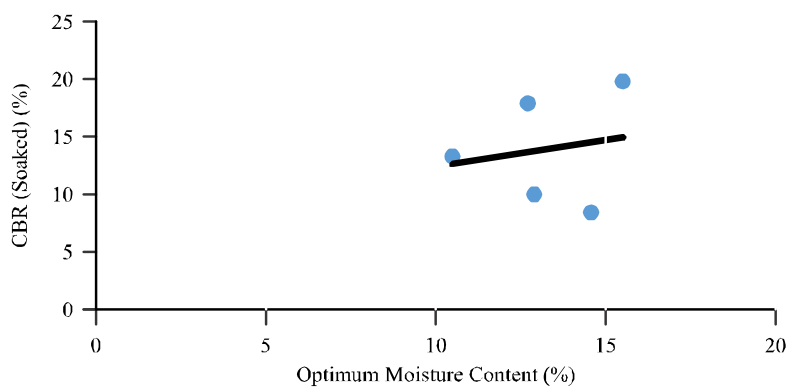

FIG. 13. RELATIONSHIP OF SOAKED CBR WITH OPTIMUM MOISTURE CONTENT
Model-9: Correlation of Soaked California Bearing Ratio with Maximum Dry Density: Fig. 14 represents a graph, which shows a correlation between soaked CBR and MDD for all soil samples. The mathematical relation between the two parameters is shown in Equation (13). It can be seen that the reliability factor $\mathrm{R}^{2}$ obtained from this equation is 0.1136 .

$\mathrm{CBR}_{\mathrm{S}}=-15.81(\mathrm{MDD})+43.715 \quad \mathrm{R}^{2}=0.1136$

Model-10: Correlation of Soaked California Bearing Ratio with \% Finer Passing From \#200 Sieve (\%F): Fig. 15 represents a graph, which shows a correlation between soaked CBR and \% finer passing from \#200 sieve for all soil samples. The mathematical relation between the two parameters is shown in Equation (14). It can be seen that the reliability factor $\mathrm{R}^{2}$ obtained from this equation is 0.1806 which is still not significant.

$\mathrm{CBR}_{\mathrm{S}}=-0.1681(\% \mathrm{~F})+26.02 \quad \mathrm{R}^{2}=0.1806$

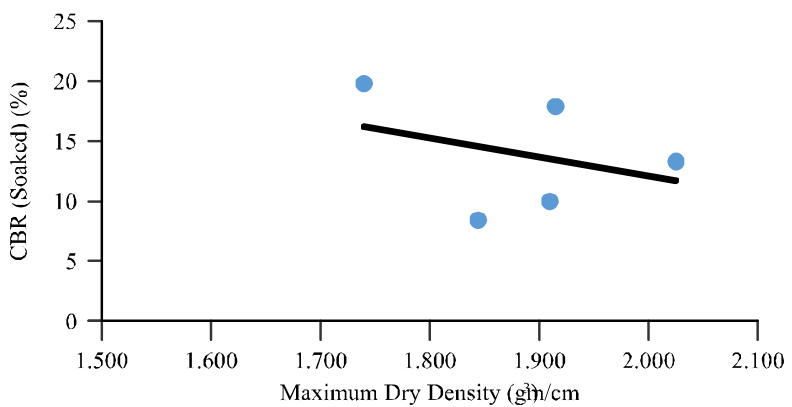

FIG. 14. RELATIONSHIP OF SOAKED CBR WITH MAXIMUM DRY DENSITY

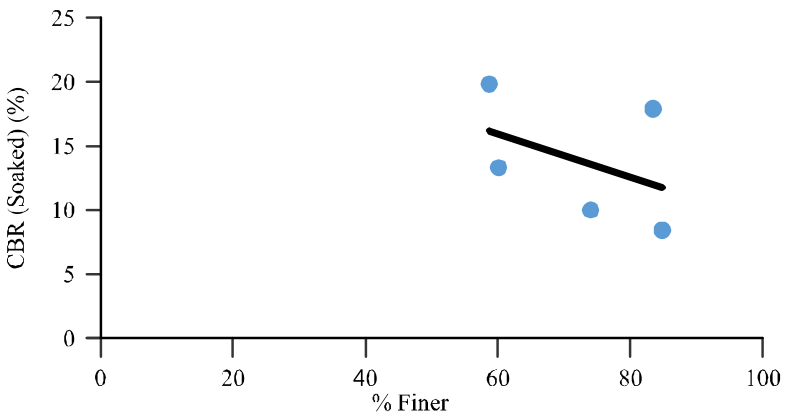

FIG. 15. RELATIONSHIP OF SOAKED CBR WITH \% FINER

Mehran University Research Journal of Engineering \& Technology, Volume 37, No. 1, January, 2018 [p-ISSN: 0254-7821, e-ISSN: 2413-7219] 
Model-11: Correlation of Soaked California Bearing Ratio $\left(\mathrm{CBR}_{\mathrm{S}}\right)$ With Unsoaked California Bearing Ratio:

Fig. 16 represents a graph, which shows a correlation between soaked CBR and unsoaked CBR for all soil samples [15]. The mathematical relation between the two parameters is shown in Equation (15). It can be seen that the reliability factor $\mathrm{R}^{2}$ obtained from this equation is 0.5153 which is still not significant.

$\mathrm{CBR}_{\mathrm{S}}=0.2807\left(\mathrm{CBR}_{\mathrm{U}}\right)+5.0352 \quad \mathrm{R}^{2}=0.5153$

A brief summary of the developed SLRA models for both Soaked and Unsoaked CBR are given in Table 3.

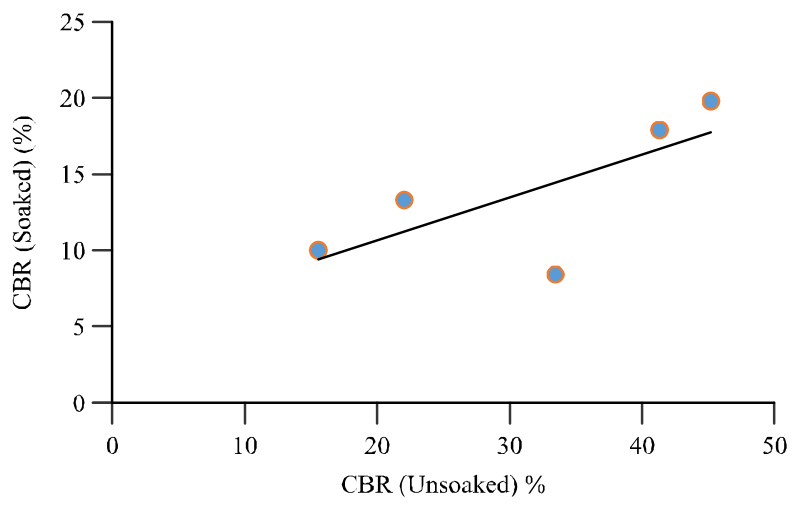

FIG. 16. RELATIONSHIP OF SOAKED CBR WITH UNSOAKED CBR
From the above developed SLRA models for unsoaked CBR, based on the values of coefficient of determination $\left(\mathrm{R}^{2}\right)$, it has been noted that Model-4 provides a better correlation with MDD with value of $\mathrm{R}^{2}=0.4413$. Similarly, for soaked CBR, Model-10 provides a better correlation with \% Finer with value of $\mathrm{R}^{2}=0.1806$.

On the other hand, the correlation between soaked and unsoaked CBR has been found to be a bettercorrelation with a value of $\mathrm{R}^{2}=0.5153$.

\subsection{Correlations By Multiple Linear Regression Analysis}

This analysis has been performed by taking CBR as function of more than one independent variables [Equation (1)]. Now, the equations which have been obtained through MLRA by adopting Microsoft Excel solution are given in Table 4 along with their model number.

From the above developed MLRA models for Soaked CBR, based on the values of coefficient of determination $\left(\mathrm{R}^{2}\right)$ and Adjusted Coefficient of Determination (Adj R²), it has been noted that Model-13 provides a better correlation

TABLE 3. DEVELOPED CORRELATIONS FOR UNSOAKED AND SOAKED CBR VALUES (SLRA)

\begin{tabular}{|c|c|c|}
\hline Model No. & Correlation/Model & 0.0413 \\
\hline 1 & CBRU $=0.2896(\mathrm{LL})+17.274$ & 0.0268 \\
\hline 2 & CBRU $=0.5519(\mathrm{PI})+17.489$ & 0.3812 \\
\hline 3 & CBRU $=4.0282(\mathrm{OMC})-21.807$ & 0.4413 \\
\hline 4 & CBRU $=-79.67(\mathrm{MDD})+181.84$ & 0.0034 \\
\hline 5 & CBRU $=0.0587(\% \mathrm{~F})+27.276$ & 0.0373 \\
\hline 6 & CBRS $=0.1077(\mathrm{LL})+8.5882$ & 0.0261 \\
\hline 7 & CBRS $=0.2131(\mathrm{PI})+8.4678$ & 0.0328 \\
\hline 8 & CBRS $=0.4624(\mathrm{OMC})+7.7621$ & 0.1136 \\
\hline 9 & CBRS $=-15.81(\mathrm{MDD})+43.715$ & 0.1806 \\
\hline 10 & CBRS $=-0.1681(\% \mathrm{~F})+26.02$ & 0.5153 \\
\hline 11 & CBRS $=0.2807(\mathrm{CBRU})+5.0352$ & \\
\hline
\end{tabular}

Mehran University Research Journal of Engineering \& Technology, Volume 37, No. 1, January, 2018 [p-ISSN: 0254-7821, e-ISSN: 2413-7219] 
with LL, PI and \% Finer with value of $\mathrm{R}^{2}=0.984$ and Adjusted $\mathrm{R}^{2}=0.935$.

Similarly, for Unsoaked CBR, correlations/models developed are shown in Table 5.

From the above developed MLRA models for Unsoaked $\mathrm{CBR}$, based on the values of coefficient of determination $\left(\mathrm{R}^{2}\right)$ and Adjusted Coefficient of Determination (Adj $\mathrm{R}^{2}$ ), it can be noted that Model-32 provides a better correlation of Unsoaked CBR with LL, PI and MDD with value of $\mathrm{R}^{2}=$ 0.971 and Adjusted $\mathrm{R}^{2}=0.884$.

\section{VALIDATIONANALYSIS}

From section 4, it is observed that high reliability for CBR prediction is observed from MLRA instead of SLRA. So now, equations of MLRA are utilized for obtaining relation between predicted and actual CBR (Table 6). Also, the graph is plotted to show the difference in values between experimental and predicted CBR for each sample.For Soaked CBR:

$\mathrm{CBR}_{\mathrm{S}}=11.2525(\mathrm{LL})-26.4144(\mathrm{PI})-0.3024(\% \mathrm{~F})+153.7175(16)$ $\mathrm{R}^{2}=0.984$, Adj $\mathrm{R}^{2}=0.935$

Now, the graph between predicted and actual CBR (Soaked) along with line of equality is presented in Fig, 17. The trend line in Fig. 17 shows that the ratio of predicted to actual $\mathrm{CBR}$ value is 1 i.e. $\mathrm{P} / \mathrm{A}=1$. Points above this line of equality indicate those samples whose predicted CBR value is higher than their actual CBR value

TABLE 4. DEVELOPED CORRELATIONS FOR SOAKED CBR VALUE (MLRA)

\begin{tabular}{|c|c|c|}
\hline Model No. & Correlation/Model & $\mathrm{R}^{2}$ \\
\hline 1 & CBRS $=7.9602(\mathrm{LL})-18.5855(\mathrm{PI})+94.8082$ & 0.478 \\
\hline 2 & $\mathrm{CBRS}=0.0729(\mathrm{LL})+0.2140(\mathrm{OMC})+7.4679$ & 0.040 \\
\hline 3 & $\mathrm{CBRS}=60.1486-0.0954(\mathrm{LL})-22.0345(\mathrm{MDD})$ & 0.125 \\
\hline 4 & CBRS $=0.0992(\mathrm{LL})-0.1655(\% \mathrm{~F})+20.9566$ & 0.212 \\
\hline 5 & $\mathrm{CBRS}=0.0824(\mathrm{PI})+0.3456(\mathrm{OMC})+7.2138$ & 0.035 \\
\hline 6 & $\mathrm{CBRS}=66.5421-0.2981(\mathrm{PI})-23.8927(\mathrm{MDD})$ & 0.135 \\
\hline 7 & $\mathrm{CBRS}=0.1836(\mathrm{PI})-0.1651(\% \mathrm{~F})+21.1395$ & 0.200 \\
\hline 8 & CBRS $=$ 537.9573-10.4525(OMC)-204.4219(MDD) & 0.726 \\
\hline 9 & $\mathrm{CBRS}=0.6217(\mathrm{OMC})-0.1812(\% \mathrm{~F})+18.7382$ & 0.239 \\
\hline 10 & CBRS $=$ 54.7316-15.3367(MDD)-0.1650(\%F) & 0.287 \\
\hline 11 & $\mathrm{CBRS}=9.1437(\mathrm{LL})-21.0468(\mathrm{PI})-0.8825(\mathrm{OMC})+110.8469$ & 0.524 \\
\hline 12 & $\mathrm{CBRS}=7.9210(\mathrm{LL})-18.5035(\mathrm{PI})-0.4965(\mathrm{MDD})+95.5896$ & 0.478 \\
\hline 13 & CBRS $=11.2525(\mathrm{LL})-26.4144(\mathrm{PI})-0.3024(\% \mathrm{~F})+153.7175$ & 0.984 \\
\hline 14 & CBRS = 589.7867-0.1925(LL)-10.8470(OMC)-224.1055(MDD) & 0.773 \\
\hline 15 & CBRS $=18.8030-0.0064(\mathrm{LL})+0.6442(\mathrm{OMC})-0.1819(\% \mathrm{~F})$ & 0.239 \\
\hline 16 & CBRS = 73.0295-0.1057(LL)-22.2298(MDD)-0.1663(\%F) & 0.302 \\
\hline 17 & CBRS = 596.3103-0.5054(PI)-10.8681(OMC)-225.6242(MDD) & 0.787 \\
\hline 18 & CBRS $=19.9079-0.1233(\mathrm{PI})+0.8015(\mathrm{OMC})-0.1870(\% \mathrm{~F})$ & 0.243 \\
\hline 19 & CBRS $=81.3928-0.3450(\mathrm{PI})-24.6802(\mathrm{MDD})-0.1686(\% \mathrm{~F})$ & 0.316 \\
\hline 20 & $\mathrm{CBR}($ Soaked $)=938.5039-19.3692(\mathrm{OMC})-366.2257(\mathrm{MDD})+0.3156(\% \mathrm{~F})$ & 0.917 \\
\hline
\end{tabular}

Mehran University Research Journal of Engineering \& Technology, Volume 37, No. 1, January, 2018 [p-ISSN: 0254-7821, e-ISSN: 2413-7219] 
and vice versa. From Fig. 17, it is observed that predicted CBR values of Sample-1, 6 and 7 slightly deviate from the line of equality while the remaining samples predicted CBR values scatters near the line of equality.

The difference between experimental/actual and predicted CBR values is graphically shown below:
Fig. 18 represents difference in values of predicted and actual CBR value in soaked condition for each soil sample in a graphical format. It can be seen that predicted CBR values of Samples 2, 5 and 6 under estimate their actual CBR values, but for Sample 1 and 7, predicted CBR values over estimate their actual CBR values. Fig. 18 depicts the results of Soaked CBR value obtained from laboratory results as well as model.

TABLE 5. DEVELOPED CORRELATIONS FOR UNSOAKED CBR VALUE (MLRA)

\begin{tabular}{|c|c|c|}
\hline Model No. & Correlation/Model & $\mathrm{R}^{2}$ \\
\hline 21 & $\mathrm{CBRU}=293.4964+25.4466(\mathrm{LL})-59.5422(\mathrm{PI})$ & 0.734 \\
\hline 22 & $\mathrm{CBRU}=6.8302(\mathrm{OMC})-0.8217(\mathrm{LL})-18.4886$ & 0.529 \\
\hline 23 & $\mathrm{CBRU}=374.0235-1.1153(\mathrm{LL})-152.4578(\mathrm{MDD})$ & 0.685 \\
\hline 24 & $\mathrm{CBRU}=0.2930(\mathrm{LL})+0.0663(\% \mathrm{~F})+12.3209$ & 0.046 \\
\hline 25 & $\mathrm{CBRU}=6.9941(\mathrm{OMC})-2.0923(\mathrm{PI})-7.8884$ & 0.560 \\
\hline 26 & $\mathrm{CBRU}=392.0103-2.7448(\mathrm{PI})-154.0842(\mathrm{MDD})$ & 0.720 \\
\hline 27 & $\mathrm{CBRU}=0.5640(\mathrm{PI})+0.0678(\% \mathrm{~F})+12.2863$ & 0.031 \\
\hline 28 & $\mathrm{CBRU}=474.0850-6.1806(\mathrm{OMC})-191.1960(\mathrm{MDD})$ & 0.474 \\
\hline 29 & $\mathrm{CBRU}=4.0517(\mathrm{OMC})-0.0268(\% \mathrm{~F})-20.1844$ & 0.382 \\
\hline 30 & $\mathrm{CBRU}=0.0751(\% \mathrm{~F})-79.8853(\mathrm{MDD})+176.8267$ & 0.447 \\
\hline 31 & $\mathrm{CBRU}=19.5963(\mathrm{LL})-47.3755(\mathrm{PI})+4.3622(\mathrm{OMC})+214.2133$ & 0.904 \\
\hline 32 & $\mathrm{CBRU}=17.3174(\mathrm{LL})-42.5467(\mathrm{PI})-102.9336(\mathrm{MDD})+455.5159$ & 0.971 \\
\hline 33 & $\mathrm{CBRU}=28.4911(\mathrm{LL})-66.7818(\mathrm{PI})-0.2796(\% \mathrm{~F})+347.9718$ & 0.800 \\
\hline 34 & CBRU = 795.1081-1.1925(LL)-8.6238(OMC)-313.1128(MDD) & 0.748 \\
\hline 35 & $\mathrm{CBRU}=7.0988(\mathrm{OMC})-0.8712(\mathrm{LL})-0.1136(\% \mathrm{~F})-11.4105$ & 0.541 \\
\hline 36 & CBRU = 369.2812-1.1115(LL)-152.3859(MDD)-0.0612(\%F) & 0.689 \\
\hline 37 & $\mathrm{CBRU}=$ 809.8604-2.9083(PI)-8.5721(OMC)-313.1981(MDD) & 0.782 \\
\hline 38 & $\mathrm{CBRU}=1.0451-2.2370(\mathrm{PI})+7.3149(\mathrm{OMC})-0.1316(\% \mathrm{~F})$ & 0.576 \\
\hline 39 & $\mathrm{CBRU}=387.9331-2.7319(\mathrm{PI})-153.8680(\mathrm{MDD})+0.0463(\% \mathrm{~F})$ & 0.722 \\
\hline 40 & $\mathrm{CBRU}=1443.6615-27.7645(\mathrm{OMC})-582.8637(\mathrm{MDD})+0.7639(\% \mathrm{~F})$ & 0.645 \\
\hline
\end{tabular}

TABLE 6. VALIDATION OF DEVELOPED CORRELATION FOR SOAKED CBR

\begin{tabular}{|c|c|c|c|}
\hline Sample No. & Actual CBR Value (\%) & Predictive CBR Value (\%) & Difference in Values \\
\hline 1 & 8.418 & 9.262 & -0.844 \\
\hline 2 & 17.892 & 17.396 & 0.496 \\
\hline 5 & 13.302 & 13.161 & 0.141 \\
\hline 6 & 10.002 & 9.363 & 0.639 \\
\hline 7 & 19.805 & 20.225 & -0.420 \\
\hline
\end{tabular}

Mehran University Research Journal of Engineering \& Technology, Volume 37, No. 1, January, 2018 [p-ISSN: 0254-7821, e-ISSN: 2413-7219] 
For Unsoaked CBR,

$\mathrm{CBR}_{\mathrm{U}}=17.3174(\mathrm{LL})-42.5467(\mathrm{PI})-102.9336(\mathrm{MDD})+455.5159$

$$
\mathrm{R}^{2}=0.971 \text {, Adj } \mathrm{R}^{2}=0.884
$$

Now, the graph between predicted and actual CBR (Unsoaked) along with line of equality is presented in Fig. 19. It is observed that predicted CBR values of Sample 1, 5 and 7 slightly deviate from the line of equality while the remaining samples predicted CBR values scatters near the line of equality. Moreover, the predicted CBR values of Sample 1, 2 and 6 are higher than their actual CBR values while the predicted CBR values of Sample 5 and 7 are lower than their actual CBR values (Table 7). The difference between experimental/actual and predicted CBR values is shown graphically below:

Fig. 20 represents difference in values of predicted and actual CBR value in unsoaked condition for each soil sample in a graphical format. It can be clearly seen that predicted CBR values of Sample 5 and 7 under estimate their actual CBR values, but for Sample 1, 2 and 6, predicted CBR values over estimate their actual CBR values.

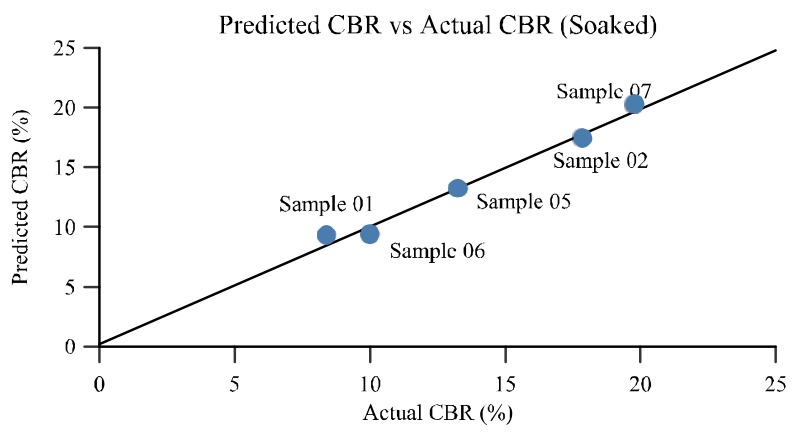

FIG. 17. GRAPH OF PREDICTED VS ACTUAL CBR IN SOAKED CONDITION

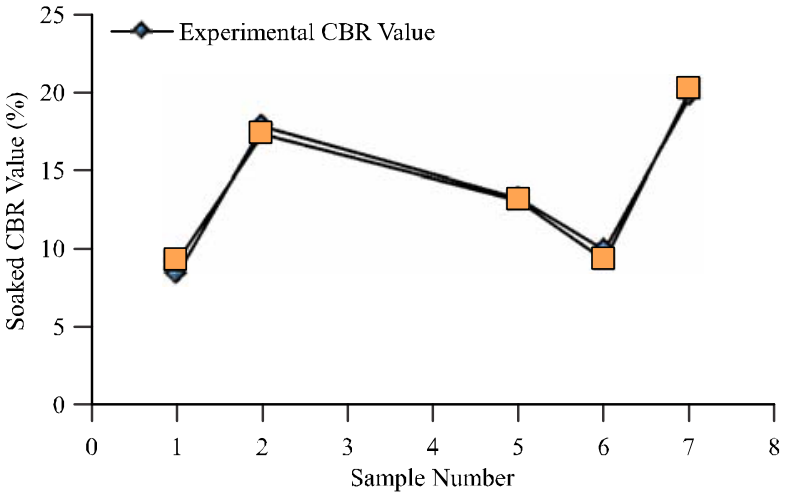

FIG. 18. GRAPH OF CBR VALUE VS SAMPLE NUMBER IN SOAKED CONDITION

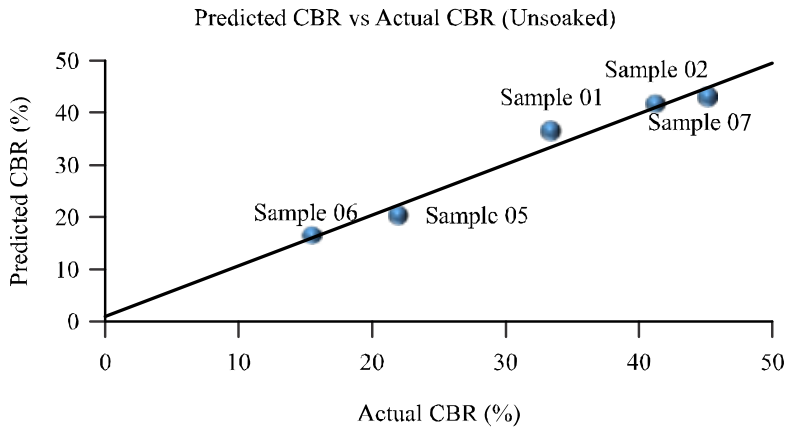

FIG. 19. GRAPH OF PREDICTED VS ACTUAL CBR IN UNSOAKED CONDITION

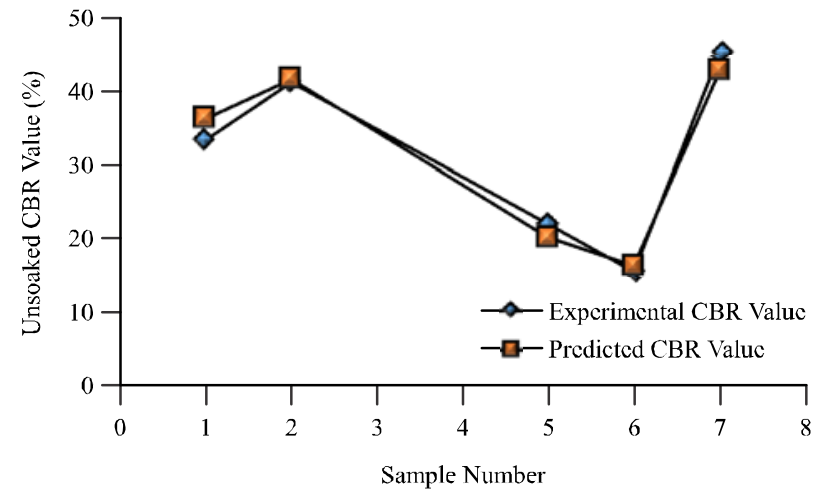

FIG. 20. GRAPH OF CBR VALUE VS SAMPLE NUMBER IN UNSOAKED CONDITION

TABLE 7. VALIDATION OF DEVELOPED CORRELATION FOR UNSOAKED CBR Difference In Values

\begin{tabular}{|c|c|c|c|}
\hline Sample No & Actual CBR Value (\%) & Predicted CBR Value (\%) & Difference In Values \\
\hline 1 & 33.465 & 36.379 & -2.914 \\
\hline 2 & 41.310 & 41.745 & -0.435 \\
\hline 5 & 22.059 & 20.232 & 1.827 \\
\hline 6 & 15.571 & 16.405 & -0.834 \\
\hline 7 & 45.185 & 42.831 & 2.354 \\
\hline
\end{tabular}

Mehran University Research Journal of Engineering \& Technology, Volume 37, No. 1, January, 2018 [p-ISSN: 0254-7821, e-ISSN: 2413-7219] 


\section{CONCLUSION}

From the results of the research, the following conclusions can be drawn:

(i) Based on the above laboratory tests, no any reliable SLRA relationship exists for predicting Soaked as well as Un-Soaked CBR value from index properties.

(ii) The highest coefficient of determination obtained for Soaked CBR is 0.1806 while correlating Soaked CBR with \% finer, and the highest coefficient of determination obtained for Un-Soaked CBR is 0.4413 while correlating UnSoaked CBR with MDD.

(iii) Un-Soaked CBR value provides a relationship with MDD through SLRA with coefficient of determination $\mathrm{R}^{2}=0.4413$, which is not suitable.

(iv) The correlation of Soaked CBR with LL, PI and \%Finer by utilizing MLRA approach gives a good relationship with $\mathrm{R}^{2}=0.984$ which is $\mathrm{CBR}$ (Soaked) $=11.2525(\mathrm{LL})-26.4144(\mathrm{PI})-0.3024(\% \mathrm{~F})+153.7175$
The correlation of Un-Soaked CBR with LL, PI and MDD by utilizing MLRA approach gives a good relationship with $\mathrm{R}^{2}=0.971$, CBR (UnSoaked) $=17.3174(\mathrm{LL})-42.5467(\mathrm{PI})$ 102.9336(MDD) + 455.5159

It is observedthat CBR values decreases with increase in PI and increases with increase in LL.

From the developed correlation, it can be seen that the Soaked CBR value is largely dependent on LL and PI of soil whereas, the effect of \% Finer is minor.

For Unsoaked CBR, the values are largely dependent on LL, PI and MDD.

\section{ACKNOWLEDGMENT}

The authors would like to thank the Geotechnical Laboratory, Department of Civil Engineering, Mehran University of Engineering \& Technology, Jamshoro, Pakistan, for providing valuable suggestions and giving a helping hand in conducting of this research work.

\section{REFERENCES}

[1] Ramasubbarao, G.V., and Siva, S.G., "Predicting Soaked CBR Value of Fine Grained Soils using Index and Compaction Characteristics”, Jordan Journal of Civil Engineering, Volume 7, No. 3, pp. 354-360, Jordan, 2013.

[2] Venkatasubramanian, C., and Dhinakaran, G., "ANN Model for Predicting CBR from Index Properties of Soil”, International Journal of Civil and Structural Engineering, Volume 2, No. 2, pp. 605-611, India, 2011.

[3] Patel, R.S., and Desai, M.D., "CBR Predicted by Index Properties for Alluvial Soils of South Gujarat”, Proceedings of Indian Geotechnical Conference, pp. 79-82, India, December 16-18, 2010.

[4] Janjua, Z.S., and Chand, J., "Correlation of CBR with Index Properties of Soil”, International Journal of Civil Engineering and Technology, Volume 7, No. 5, pp. 57-62, India, 2016.

[5] Shirur, N.B., and Hiremath, S.G., "Establishing Relationship between CBR Value and Physical Properties of Soil”, IOSR Journal of Mechanical and Civil Engineering, Volume 11, No. 5, pp. 26-30, India, 2014.

[6] Patel, M.A., and Patel, H.S., "Correlation between Physical Properties and California Bearing Ratio Test on Soils of Gujarat Region in Both Soak and Un-Soak Condition”, International Journal of Civil Engineering and Technology, Volume 3, No. 2, pp. 50-59, India, 2012.

[7] Kumar, A., and Khaskheli, G.B., "Effect of Cement Content on Unconfined Compressive Strength of Jamshoro Soil”, Proceedings of International Symposium on Sustainable Geosynthetics and Green Technology for Climate Change, pp. 169-175, Thailand, June 20-21, 2012. 
[8] Kumar, A., Khaskheli, G.B., and Phul, A.M., "Effect of Marble Powder on Various Geotechnical Properties of Jamshoro Soil”,Proceedings of $3{ }^{\text {rd }}$ International Conference on Construction in Developing Countries, pp. 695-700, Thailand, July 4-6, 2012.

Kumar, A., Khaskheli, G.B., and Korejo, R., "Improving CBR Value and Swelling Potential of Jamshoro Soil by Cement”, Proceedings of $7^{\text {th }}$ Regional Symposium on Infrastructure Development, pp. 1-5, Thailand, November 5-7, 2015.

Rakaraddi, P.G., and Gomarsi, V., "Establishing Relationship between CBR with Different Soil Properties”, International Journal of Research in Engineering and Technology, Volume 4, No. 2, pp. 182-188, India, 2015.
Das, B.M., "Principles of Geotechnical Engineering", $7^{\text {th }}$ Edition CL Engineering Publisher, USA, 2009.

[12] Punmia, B.C., Kumar, A., and Jain, A.K., "Soil Mechanics \& Foundation Engineering”, 16 $6^{\text {th }}$ Edition, Laxmi Publisher, India, 2015,

[13] Garg, S.K., "Soil Mechanics \& Foundation Engineering”, $4^{\text {th }}$ Revised Edition, Khanna Publisher, India, 2001.

[14] ASTM D1883-07, “Standard Test Method for CBR (California Bearing Ratio) of Laboratory-Compacted Soils”, American Society for Testing and Materials, USA, 2007.

[15] Ahmed, S.S., Hossain, N., Khan, A.J., and Islam, M.S., "Prediction of Soaked CBR using Index Properties, Dry Density and Unsoaked CBR of Lean Clay", Malaysian Journal of Civil Engineering Volume 28, No. 2, pp. 270-283, Malaysia, 2016. 